the choice of methods for the attack of each special Problem.

His Elementary Physics, and his Conservation of Energy, are popular works on physics rather than scientific treatises:-but his Treatise on Heat is one of the best in any language, a thoroughly scientific work, specially characteristic of the bent of mind of its Author.

Stewart published, in addition to his Kew Reports, a very large number of scientific memoirs and short papers. Many of these (notably the article in the Encyc. Brit., 9th edn.) deal with Terrestrial Magnetism, in itself as well as in its relations to the Aurora and to solar disturbances. A valuable series of papers, partly his own partly written in conjunction with De la Rue and Lœwy, deals with Solar Physics. His paper on the Occurrence of Flint Implements in the Drift (Phil. Mag. 1862, I.) seems to have been ignored by the "advanced" geologists, one of whose pet theories it tends to dethrone; and to have been noticed only by physicists, especially Sir W. Thomson, whose beautiful experiments have done so much to confirm it. His paper on Internal Radiation in Uniaxal Crystals, to which Stokes alone seems to have paid any attention, shows what Stewart might have done in Mathematical Physics, had he further developed the genuine mathematical power which he exhibited while a student of Kelland's.

I made Stewart's acquaintance in $\mathrm{I} 86 \mathrm{r}$, when he was the first-appointed Additional Examiner in Mathematics in the University of Edinburgh, a post which he filled with great distinction for five years. A number of tentative investigations ultimately based upon our ideas as to possible viscosity of the luminiferous medium, effect of gravitation-potential on the physical properties of matter, \&c., led to the publication of papers on Rotation of a disc in vacuo, Observations with a rigid spectroscope, Solar spots and planetary configurations, \&c. These, as well as our joint work called The Unseen Universe, have been very differently estimated by different classes of critics. Of course I cannot myself discuss their value. There is, however, one of these speculations, so closely connected with Stewart's Radiation work as to require particular mention, especially as it seems not yet to have received proper consideration, viz. Equilibrium of Temperature in an cnclosure containing matter in visible motion. (NATURE, I87I ; iv. 33I.) The speculations are all of a somewhat transcendental character, and therefore very hard to reduce to forms in which they can be experimentally tested; but there can be no doubt that Stewart had the full conviction that there is in them all an underlying reality, the discovery of whose exact nature would at once largely increase our knowledgre.

Of the man himself I cannot trust myself to speak. What I could say will easily be divined by those who knew him intimately; and to those who did not know him I am unwilling to speak in terms which, to them, would certainly appear exaggerated.

P. G. TAIT.

\section{CHRISTMAS ISLAND.}

PROFESSOR NEWTON sends us the following extracts from a letter received by him from $\mathrm{Mr}$. J. J. Lister, M.A., St. John's College, Cambridge, the naturalist on board H.M.S. Egeria, Commander Aldrich, R.N., describing the recent visit to that little-known island:-

"We left Batavia on Tuesday, September 27, about 5 a.m., and were in the Straits of Sunda by the afternoon. We saw the hills on the Java side clearly, scored by many steep-sided valleys, and the green of the fields contrasting brightly with the red volcanic earth. Behind these nearer hills one of the great conical mountains loomed out every now and then from his covering of clouds. To the west- ward, and more distant, a high volcanic peak on the main island of Sumatra rose above nearer islands, and later in the afternoon we saw the simple conical mass of Krakatao. N'ext day we were bouncing about in deep blue water, as we steamed south against a head-wind-a change after the quiet sailing over the pale green shallow seas in which we had been since we entered the Straits of Malacca. On Friday, September 30, we reached Christmas Island. The first we saw of it was a long line against the southeast horizon, with a shallow saddle in the middle and a gradual rise at either end-that to the west being the higher. On nearer approach the island was seen to be uniformly covered with trees, with a low cliff, much undermined at the water's edge; above this a gradual slope leads to another steep ascent, which in some places, especially at the projecting headlands, is a bare cliff, in others covered with trees. From this there is a gradual rise to the top. We found that there is a cap of coral limestone over the whole island. The top is formed of gray pinnacled masses with steep fissures between them, and the surface of the rock is worn into a rough honeycomb with sharp points and ridges which break under foot and show the glistening white rock. On the slope of the island this rock forms horizontal terraces, with a rough slope of pinnacled masses or a sheer cliff leading down from them, and these seemed to be in a general way continuous at the same level along the side of the island. I suppose they mark the pauses in its gradual elevation during which a fringing reef has formed. Some pieces of rock, apparently volcanic, were picked up at Flying-fish Cove, but it was not found where they had fallen from.

"No stream or standing water was found. Apparently all the rain that falls soaks into the porous rock at once. The vegetation, however, looked fresh and green, and the under parts of fallen logs were sodden with moisture. On two of the nights during the ten days we were there, there was heavy rain; otherwise we had fine weather. Many of the trees are tall, reaching 150 to 170 feet or more, and some of them have vertical buttresses at the base, which wind about horizontally and give off secondary buttresses. They are often laden with great clumps of birds'-nest ferns, as well as with other ferns, orchids, and parasitical trees, and their trunks are festooned with long straight lianas. I only found two orchids with flowers out, but these were small and inconspicuous. Along the shore there are tangled thickets of screw pines, and another kind grows on the higher part. A large proportion of the trees bear edible fruits. Altogether I am sending home some fifty kinds of flowering plants and fifteen of ferns.

"The rat (Mus macleari) swarms on the island. They come out at dusk, and run about, in and out of the tents that were pitched by the shore, through the night. There is another kind of rat which is larger and black, except where the scanty fur on the feet allows the pale skin to show. There is also a shrew mouse, whose short shrill squeak may often be heard in the woods. I caught three of them one night in a pitfall. Several specimens of the fruit-eating bat (Pteropus natalis) were obtained, including males, which have no pale-coloured tippet, as $\mathrm{Mr}$. Thomas [P.Z.S., I887, p. 512] thought miglit possibly be the case. There is a small insectivorous bat in the island, but I did not succeed in getting one.

"The large fruit-eating pigeon (Carpophaga whartoni) is very common. They congregate in the fruit-bearing trees, and may then be shot by the dozen. They are excellent eating, and supplied fresh meat for the ship.

"There is a small dove-brown, with a rich bronzy-green on the back and wings-which is very common. Their habits are remarkably in keeping with their colouring. On trees they are restless and seldom seen, but on the ground, among fallen brown and green leaves, where their colour makes them very inconspicuous, they seem to have no fear. I shot seven one morning close to our place : they were feeding in pairs on fallen berries, and 
when one of a pair was shot, the other went on feeding as though nothing had happened.

"The thrush (Turdus erythropleurus) is very abundant, and as tame as possible. None of my specimens show any mottling, but Capt. Aldrich told me that he saw one with the breast mottled. The bill and feet are as yellow as a cock blackbird's. I heard no song, but they often give a 'chick-chick—-chick-chick-chick-chick,' quickening time at the finish.

"Parties of twelve to twenty of a species of Zosterops were very common. They had just-fledged young ones among them.

"The other birds we obtained were two hawks, an owl, a swift, a heron, a plover, and a sandpiper. Besides these, frigate-birds, gannets, boobies, and boatswain-birds of two kirids were everywhere abundant.

"We obtained three kinds of lizards, and the Typhlops which was found before, but no tortoises. We saw a turtle making off down the beach early one morning, but it got into the sea before it could be turned over.

"We saw no frogs, and heard none.

"We found five kinds of land-shells, four of butterflies, a few moths, and some eighteen species of beetles, besides spiders, centipedes, \&c. I have one of the hawks alive, which I hope to be able to bring home to England. . . . . "J. J. LisTER."

Accounts have been received from Captain Aldrich, R.N., of H.M. surveying-vessel Egeria, of a recent visit to Christmas Island in the Indian Ocean, made in consequence of the interest attaching to the small collection recently brought thence by Captain Maclear, R.N., (see NATURE, vol. xxxvi. p. r2). Mr. J. J. Lister kindly volunteered to act as naturalist, and proceeded from England to Colombo, whence he took a passage in the Egeria for the purpose of collecting.

Captain Aldrich states that the highest point of the island was reached at the expense of considerable labour, but without as much difficulty as was anticipated. This point is 1200 feet high, and not, as was before incorrectly stated, 1580 feet.

The island is coral-clad to the very top, the actual summit being a block of coralline limestone, worn and undermined. No rock other than of a calcareous nature was met with in the island, though a diligent search was made, and holes dug where the soil appeared thickest.

Three tiers of cliffs, probably marking sea-levels, intervene between the top of the existing sea cliffs and the summit. Breaches in these cliffs afforded means of scaling them, aided by the numerous aerrial roots of the trees with which the island is densely covered.

Between the cliffs the ground rises irregularly, being covered in some places with soil apparently deep, intermixed with fragments of coral. Tangled jungle and high forest grow everywhere. The vertical rise to the summit where ascended takes place in the following manner, as described by Captain Aldrich :-

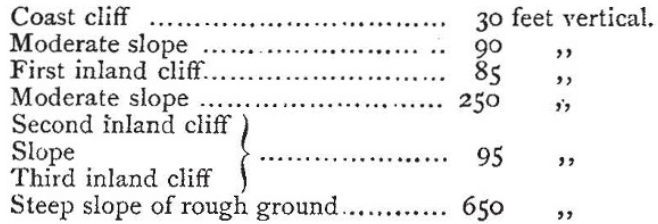

The total horizontal distance is about 5000 feet.

Christmas Island therefore appears to be a remarkable instance of the complete casing with coral of an island which, from the time that its nucleus first came within the reef-building zone, has been steadily subjected to a movement of upheaval, varied by pauses, during which the cliffs were eroded by the sea. So far as I am aware, no case of similar magnitude has yet been recorded.
The collections now on their way to England are, it is feared, not so varied as was anticipated from the samples of life brought home by the Flying Fish.

A considerable number of interesting photographs were obtained by the officers, and accompany Captain Aldrich's report, which will be published.

The Egeria has obtained a line of soundings across the hitherto unfathomed area of the southern Indian Ocean, between the Strait of Sunda and Mauritius, but no details have as yet come to hand.

December 17.

$$
\text { W. J. L. WHARTON. }
$$

\section{TIMBER, AND SOME OF ITS DISEASES. ${ }^{1}$}

\section{II.}

T $\mathrm{HE}$ enormous variety presented by the hundreds of different kinds of woods known or used in different countries depends for the most part on such peculiarities as I have referred to above, together with some others which have not as yet been touched upon. Everybody knows something of the multitudinous uses to which timber is put, and a little reflection will show that these uses are dependent upon certain general properties of the timber. Speaking broadly, the chief properties are its weight, hardness, elasticity, cohesion, and power of resisting strains, \&c., in various directions, its durability in air and in water, and so forth; moreover, special uses demand special properties of other kinds also, and the colour, closeness of texture, capacity for receiving polish, \&c., come into consideration.

Now, there is no doubt that the structure of the wood as formed by the cambium is the chief factor in deciding these technological characters: it is not the only factor, but it is the most important one. Consequently no surprise can be felt that those who are interested in timber have of late years turned their attention to this subject with a view to ascertain as much as possible about this structure, and to see whether it can be controlled or modified, what dangers it is subject to, and how far a classification of timbers can be arrived at. The more the subject is studied, the more interesting and practically important the matter becomes. The results already obtained (though the study is as yet only in its infancy), have thrown brilliant light on several burning questions of physiology-as witness the researches of Sachs, Hartig, Elfving, and Godlewski, on that old puzzle, to account for the ascent of water in tall trees. The study is, moreover, of first importance for the comprehension of the destruction of timber, due to "dry-rot" and the parasites which cause diseases in standing trees, as is shown by the brilliant researches of Prof. R. Hartig on the destruction of timber by Hymenomycetes; and again as yielding trustworthy information as to the value of different kinds of timber in the arts, and enabling us to recognize foreign or new woods of value. In support of this statement it is only necessary to call attention to the "Manual of Indian Timbers," prepared for the Indian Government by Mr. Gamble; or to refer to the beautiful series of woodsections prepared by Nördlinger.

It is, of course, impossible in an article like the present to do more than touch upon a few of the more interesting points in this connection; but I may shortly summarize ono or two of the more striking of these peculiarities of timbers, if only to show how well worth further investigation the matter is.

Many timbers, from both tropical and temperate climates, exhibit the so-called "annual rings" on the transverse section; but this is not the case with all. Most European timbers, for instance, are clearly composed of such layers; but in some cases the layers ("rings" on the transverse section) are so narrow and

\footnotetext{
${ }^{I}$ Continued from p. 186
} 